\title{
EFFECT OF AUSTRIAN PINE ON NATURALNESS AND SUCCESSION OF VEGETATION IN RECLAIMED BAUXITE QUARRIES
}

\author{
CSERESNYÉS, I. ${ }^{1}$ - CSERESNYÉs-BÓZSING, E. ${ }^{2}-$ TAMÁs, J. ${ }^{3}$ - BARINA, Z. ${ }^{3}-$ CSONTOS, P. ${ }^{1}$ * \\ ${ }^{I}$ Institute for Soil Sciences and Agricultural Chemistry, Centre for Agricultural Research, \\ Hungarian Academy of Sciences, H-1022 Budapest, Herman Ottó út 15, Hungary \\ (phone: +36-1-2122265; fax: +36-1-2122265) \\ ${ }^{2}$ Department of Environmental Analysis, Central Environmental and Food Research Institute, \\ H-1022 Budapest, Herman Ottó út 15, Hungary \\ (phone: +36-1-3558991; fax: +36-1-2129853) \\ ${ }^{3}$ Department of Botany, Hungarian Natural History Museum, H-1476 Budapest, P.O. Box 222, \\ Hungary \\ (phone: +36-1-2101330; fax: +36-1-3812188) \\ *Corresponding author \\ e-mail: cspeter@rissac.hu \\ (Received $5^{\text {th }}$ July 2013; accepted $22^{\text {nd }}$ June 2014)
}

\begin{abstract}
Phytosociological and nature conservation assessment of the herb layer of 6-, 15- and 20-yearold post-mining Austrian pine stands was conducted in reclaimed bauxite quarries in Hungary. Great differences among the vegetations were found. Disturbance-tolerant species were dominant, subdominant and subordinated in the youngest, middle-aged and oldest pine stand, respectively. In parallel, proportion of the species characteristic for natural habitats increased gradually, leading to growing diversity and naturalness. The increasing pine cover reduced the species number and the coverage of herb layer. Postmining flora differed significantly from both the potential mature oak forest vegetation of the areas and from the associations developed through regenerative succession on clear-cut areas of oak forests. Vegetation of the reclaimed quarries had lower naturalness: relative abundances of disturbance-tolerant and ruderal species were higher, but ratio of natural broad-leaved forest's species was smaller than in the potential vegetation. Similar differences were shown by comparison of the flora of bauxite quarries with the same-aged stages of regenerative succession of oak forests. In pine stands the repression of weeds parallel to the spreading of natural competitors was slower, and natural geophytes and protected species remained absent. Deficiency of propagule sources in reclaimed areas could contribute to the retentive effect of Austrian pine on vegetation succession.
\end{abstract}

Keywords: Pinus nigra, bauxite quarries, phytosociological succession, naturalness value, reclamation

\section{Introduction}

At present, an area of 67200 hectares is covered by the monodominant stands of the alien Austrian pine (Pinus nigra Arn.) in Hungary (source: NFCSO, Hungarian Forest Management Inventory, 2013). Although these plantations occupy only $3.7 \%$ of the total forested lands of the country, P. nigra is responsible for some serious ecological and nature conservation problems (Tamás, 2003). Several studies called the attention to the various aftermaths of the creation of pine stands, such as to the effects on the soil and ground layer including serious impoverishment of the species-rich native grassland vegetation (Bódis, 1993; Csontos et al., 1997, 2012, Szalai et al., 2012), the promoted spreading of other alien plants (Török et al., 2003; Cseresnyés and Csontos, 2012a), as 
well as the highly increased fire risk as a consequence of the considerable accumulation of resinous needle litter (Cseresnyés et al., 2011).

Austrian pine has been widely used for biological reclamation of various degraded areas in several European countries since the 1950s (Fettweis et al., 2005; Zagas et al., 2010). In Hungary, successful afforestations were executed on open-pit dolomite, bauxite, lignite and brown coal mines, waste-rock piles, rubbish dumps, slag heaps and red sludge reservoirs (Szerémy, 1981; Baranyi, 1986; Horváth, 2002; Károly et al., 2006). The good applicability of Austrian pine is presumably related to its wide scale habitat tolerance. The cover substrate deposited through the technical reclamation is generally characterized by physical and chemical conditions improper for plant cultivation, such as low nutrient supply, extreme acidity or basicity, as well as high spatial heterogeneity in texture and subsequently in water-holding and water-conducting capacity (Jochimsen, 2001). Materials of dead rocks, but particularly of slag and red sludge usually contain high level of mobile and easily mobilizable toxic heavy metals and compounds, i.e. sulphides (Liu et al., 2011). Austrian pine is quite tolerant to dry and nutrient-poor soils as well as to high concentration of toxic metals (i.e. Al, As, Cd, $\mathrm{Cu}, \mathrm{Sb}, \mathrm{Sn}, \mathrm{W}$ ) and pyrite (Pratas et al., 2005). The intensive early root expansion enables the species to uptake water and nutrients from the soil efficiently, even if unfavourable environmental conditions prevail (Richardson, 1998; Baumann et al., 2006). Soil melioration effect of the pine proved to be unsatisfactory in many cases, but the dense root system, the quick canopy closure and the intensive litter formation markedly reduce soil erosion (Filcheva et al., 2000; Miletić et al., 2011).

After land reclamation, post-restoration monitoring systems are commonly used both for examining characteristic changes in environmental factors and to study the rate and stage of area regeneration. Such type of research offers good opportunities for improving the land restoration practice. The realized monitoring activities are ordinarily include the investigation of refuse soil as well as surface and subterranean water, but the comprehensive survey of the biota in the reclaimed area is neglected in most cases. Phytosociological studies of the vegetation developed during or after biological reclamation may be of great importance in terms of future planned area utilization, particularly in case when the restoration of the botanically valuable potential vegetation is aimed. Therefore, present study was designed to investigate the vegetation of abandoned bauxite quarries reclaimed with Austrian pine and to assess the naturalness of the flora in order to evaluate the effect of the alien tree on the regenerative secondary succession.

\section{Materials and methods}

Three reclaimed bauxite quarries were chosen for study in Transdanubia, Hungary. Locations of the study sites and percentage cover of $P$. nigra are given in Table 1.

(1) 6-year-old site (6.9 ha in area). Pine stand is situated $2.6 \mathrm{~km}$ south of village Szőc, on a north-facing slope covered by the materials of former waste-rock piles. The young pine plantation is surrounded mostly by sessile oak - Turkey oak forests, grown in the neighbouring undisturbed areas. Following the open-pit bauxite mining (197786), the area was technically reclaimed until 2005 (Kovács, 1998). Sawdust and inorganic fertilizers were used in order to create a more suitable material 
Table 1. Data of Austrian pine stands established for reclamation of bauxite quarries in Hungary, and the code of quadrats used for phytosociological studies.

\begin{tabular}{|c|c|c|c|}
\hline $\begin{array}{c}\text { Study site age; code of forest } \\
\text { management unit }\end{array}$ & $\begin{array}{l}\text { Code of } \\
\text { quadrat }\end{array}$ & GPS coordinates & $\begin{array}{r}\text { Cover of } P \text {. } \\
\text { nigra }(\%)\end{array}$ \\
\hline \multirow{5}{*}{$\begin{array}{c}6 \text { years old; } \\
\text { Sáska 6I, Szöc }\end{array}$} & A1 & N 465'ㄷ‥9"; E 17³1'33.8"; 282 m & 15 \\
\hline & A2 & N 4659'59.2"; E 17³1'35.0"; 284 m & 10 \\
\hline & A3 & N 4659'58.6"; E 17³1'35.3"; 289 m & 10 \\
\hline & A4 & N 4659'57.9"; E 17³1'34.1"; 294 m & 15 \\
\hline & A5 & N 4659'57.2"; E 17³1'33.5"; $299 \mathrm{~m}$ & 15 \\
\hline \multirow{5}{*}{$\begin{array}{c}15 \text { years old; } \\
\text { Bicske } 7 \mathrm{~A}, \text { Nagyegyháza }\end{array}$} & B1 & 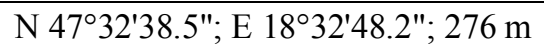 & 40 \\
\hline & B2 & N 47³2'39.3"; E 18³2'49.4"; 278 m & 70 \\
\hline & B3 & N 473'ㄴ'48.6"; E 18³2'56.1"; 297 m & 25 \\
\hline & B4 & N 47³2'47.5"; E 18³2'57.7"; $291 \mathrm{~m}$ & 90 \\
\hline & B5 & N 473'ㄴ'43.5"; E 18³2'52.1"; 290 m & 70 \\
\hline \multirow{5}{*}{$\begin{array}{l}20 \text { years old; } \\
\text { Sáska } 63 \mathrm{G}\end{array}$} & $\mathrm{C} 1$ & N 4659'49.6"; E 17³0'55.8"; $261 \mathrm{~m}$ & 20 \\
\hline & $\mathrm{C} 2$ & N 465'ㄴ‥1"; E 17³0'54.4"; 260 m & 60 \\
\hline & $\mathrm{C} 3$ & 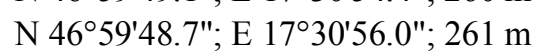 & 55 \\
\hline & $\mathrm{C} 4$ & 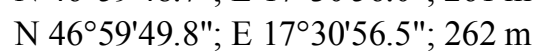 & 20 \\
\hline & $\mathrm{C} 5$ & N 4659'49.3"; E 17³0'58.3"; 263 m & 75 \\
\hline
\end{tabular}

for the afforestation, thereafter Austrian pine was cultivated by seed-sowing in 2004. In the study year (2010), pine stand height was $1-1.5 \mathrm{~m}$ with a pronounced dominance of Solidago gigantea in the herb-layer vegetation.

(2) 15-year-old site (3.2 ha in area). Post-mining pine stand is located $3.5 \mathrm{~km}$ north of village Nagyegyháza, $9 \mathrm{~km}$ northwest of the city of Bicske, surrounded by sessile oak - Turkey oak forests and artificial black locust stands. The abandonment of bauxite mining was followed by the complex reclamation in 1995 (Novák, 2007). Prior to the seed-sowing of Austrian pine, organic fertilizer and chopped bark were added and mixed the cover layer to build soil organic matter. By the study year (2010), a 3-5 m high, dense pine stand (only with local natural thinning) developed in the area predominated by Calamagrostis epigeios in the herb layer.

(3) 20-year-old site (6.4 ha in area). The area is situated $1 \mathrm{~km}$ west of the 6-year-old study site. The neighbouring vegetation was formed mainly by sessile oak - Turkey oak forests except westward where a secondary scrubland was grown (invaded by the alien black locust). Establishment of Austrian pine stands was completed in 1990 by transplanting pine saplings after meliorating the cover layer with addition of sawdust and inorganic fertilizer (Kovács, 1998). In the study year, the 4-6 $\mathrm{m}$ high pine stand had great spatial variation in density due to the local decay of trees. Species-rich herb layer was observed especially in the glades of the stand.

For floristic survey, five $10 \mathrm{~m}$ by $10 \mathrm{~m}$ permanent quadrats were randomly located within each study site at least $20 \mathrm{~m}$ from the edge of pine stand then their centres were localized with GPS instrument (Table 1). In the quadrats, canopy cover of Austrian pine was visually estimated, afterwards the percentage cover of each herb-layer species (including low shrubs) were recorded three times during the vegetation season (May/June 2010, August/September 2010 and April 2011) in order to get a complete species inventory. Species names were used after Simon (2000). For data processing, each species was considered with its maximum cover value detected during the three sampling occasions. Total number of species, average number of species per quadrat as 
well as dominant and constant species were determined for each study site. Shannon diversity (H') of sample area was calculated by merging the data of the five quadrats and using natural logarithm. In addition, the evenness (E) of the vegetation and the diversity of every single quadrat was also calculated (rare species were considered with $0.1 \%$ cover value). Shannon diversity of study sites were compared statistically by performing Hutcheson's t-test (Hutcheson, 1970). Relationships between the cover of Austrian pine and the cover, species number and Shannon diversity of the herb-layer vegetation in quadrats were analysed by using Spearman's rank correlation. For characterizing the vegetation developed since the afforestation two types of plant traits were used: (1) social behaviour type (Borhidi, 1995) and (2) Raunkiaer life-form (Simon, 2000) of the species. Based upon the mean percentage cover of species (counted by averaging the data of the five quadrats) and their plant traits, group distributions were calculated with the application of the following categories:

(1) Social behaviour type: S (specialists); C (natural competitors); G (generalists); NP (natural pioneers); DT $+\mathrm{W}$ (disturbance-tolerants and indigenous weeds); RC (indigenous ruderal competitors); $\mathrm{AC}+\mathrm{I}$ (alien competitors and introduced species). On group distribution graphs, categories are displayed in order of decreasing naturalness value (Borhidi, 1995).

(2) Raunkiaer life-form: $\mathrm{MM}+\mathrm{M}$ (Phanerophyte); Ch (Chamaephyte); $\mathrm{H}$ (Hemikryptophyte); G (Geophyte); TH (Hemitherophyte); Th (Therophyte).

The quasi-mean naturalness value of vegetation was computed for each study site, based on the naturalness value of the constituting species weighted with their cover (according to Borhidi, 1995). Vegetation of study sites was compared by applying homogeneity test on the group distributions of (1) and (2).

Comparative analyses of the studied vegetations were made in two ways:

(A) Vegetations of the reclaimed bauxite quarries were compared to mature stands of oak forests (sessile oak - Turkey oak ass. and pedunculate oak - Turkey oak ass.), the community types considered the natural climax associations of the territories surrounding the studied quarries (Zólyomi, 1989). This type of comparison was dedicated to assess how much the restored vegetations became similar to the theoretical final stage of the succession. In this way, the 15-year-old site was compared to sessile oak - Turkey oak stand relevés from the southern part of Gerecse Mountains (unpubl. data by Z. Barina), whereas the 6- and 20year-old reclaimed sites were compared to pedunculate oak - Turkey oak stand relevés from the Bakony Mountains (Szodfridt and Tallós, 1964). Since latter authors applied Braun-Blanquet scale in their work, data were converted into percentage cover by van der Maarel transformation (Maarel, 2007).

(B) Vegetations of the reclaimed quarries were compared to successional stages of the natural vegetation with comparable age. The idea of this type of comparison was to assess how much slower (or faster) the succession is in the restored vegetation sites than in sites where a spontaneous regenerative succession takes place. Csontos (2010) studied regeneration cycle of sessile oak - Turkey oak forests and identified four stages along time since clear-cutting of the stands. These stages were: $\mathrm{I}=1-3$ years old; $\mathrm{II}=4-11$ years; $\mathrm{III}=12-21$ years and $\mathrm{IV}=$ 22-28 years. Relevés from stage II were compared to the 6-year-old reclaimed vegetation, whereas the 15 and 20 years old reclaimed quarries were compared to relevés from stage III of the oak forest regeneration succession. 
The comparative analyses $(A)$ and $(B)$ were based on distributions of plant functional groups, namely social behaviour types and Raunkiaer life-forms of the vegetation, since this approach is often provides an excellent supplementation to the analysis of vegetation based only on species composition (Woźniak et al., 2011). Statistica software package (ver 9, StatSoft Inc., OK, USA) was used for the statistical analyses.

\section{Results}

Altogether 170 vascular plant species were listed in the reclaimed areas (for detailed floristic data, see Cseresnyés and Csontos, 2012b). The total number of species increased with the age of pine stand, as it was the lowest (83) in the 6-year-old stand and the highest (108) in the 20-year-old stand (Table 2). Average number of species per quadrat ranged from 48.3 (15-year-old stand) to 55.2 (20-year-old stand), while the herb layer cover varied between $39 \%$ and $95 \%$ in the 15 - and 6-year-old stand, respectively. The Shannon diversity $\left(\mathrm{H}^{\prime}\right)$ and also the evenness $(\mathrm{E})$ increased along with the increasing age of pine stand: both index proved to be the lowest in the 6-year-old stand $\left(H^{\prime}=2.220 ; E=0.502\right)$ and the highest in the 20-year-old forest $\left(H^{\prime}=2.914 ; E=0.622\right)$. Hutcheson's $t$-test showed significant $(\mathrm{p}<0.05)$ differences in diversities only between the youngest and the oldest sampling areas, while the 15-year-old study site had an intermediate position (Table 2). Number of constant species varied considerably from 6 to 19 in the 15- and 20-year-old site, respectively.

Table 2. Characteristics of the vegetations developed in bauxite quarries reclaimed with Austrian pine 6, 15 and 20 years ago, in Hungary. Superscript letters after diversity values indicate groups distinguished by Hutcheson's t-test.

\begin{tabular}{lccc}
\hline & 6-year-old & 15-year-old & 20-year-old \\
\hline Total number of species & 83 & 106 & 108 \\
Average number of species per quadrat & 50.8 & 43.8 & 55.2 \\
Average cover of herb layer (\%) & 95 & 39 & 73 \\
Shannon-diversity (H') & $2.220^{\mathrm{a}}$ & $2.538^{\mathrm{ab}}$ & $2.914^{\mathrm{b}}$ \\
Evenness (E) & 0.502 & 0.544 & 0.622 \\
Number of constant species & 19 & 6 & 17 \\
\hline
\end{tabular}

Characterization of the herb layer of study sites in association with dominant and constant species (Table 3):

(1) 6-year-old stand: Vegetation of the former waste-rock pile was dominated by the abundant Solidago gigantea (48\%), Calamagrostis epigeios (12\%) and Erigeron annuus (4.4\%). Besides, the flora was determined by the composition of the leguminous Trifolium pretense, T. repens, T. alpestre and Medicago lupulina (4-6\% cover by each) as well as the grasses Holcus lanatus and Dactylis glomerata. The high spatial homogeneity and the high number of constant species of the herb-layer vegetation observed in the area was due to the combined effect of the evenly low (10-15\%) canopy cover of Austrian pine and the young age of the stand. Each of the nine species 
Table 3. Mean percentage cover of dominant and constant species in the vegetation of reclaimed bauxite quarries of different ages.

\begin{tabular}{|c|c|c|c|c|}
\hline & Dominant species & $\%$ & Constant species & $\%$ \\
\hline \multirow{19}{*}{$\begin{array}{l}\text { 6-year-old } \\
\text { stand }\end{array}$} & Solidago gigantea & 48 & Solidago gigantea & 48 \\
\hline & Calamagrostis epigeios & 12 & Calamagrostis epigeios & 12 \\
\hline & Trifolium pratense & 6.2 & Trifolium pratense & 6.2 \\
\hline & Medicago lupulina & 5 & Medicago lupulina & 5 \\
\hline & Trifolium repens & 5 & Trifolium repens & 5 \\
\hline & Trifolium alpestre & 4.6 & Trifolium alpestre & 4.6 \\
\hline & Erigeron annuиs & 4.4 & Erigeron annuиs & 4.4 \\
\hline & Holcus lanatus & 1.8 & Holcus lanatus & 1.8 \\
\hline & Dactylis glomerata & 1.64 & Dactylis glomerata & 1.64 \\
\hline & Fragaria vesca & 1 & Fragaria vesca & 1 \\
\hline & & & Galium verum & 0.64 \\
\hline & & & Achillea collina & 0.46 \\
\hline & & & Astragalus glycyphyllos & 0.46 \\
\hline & & & Tussilago farfara & 0.46 \\
\hline & & & Cirsium arvense & 0.28 \\
\hline & & & Lotus corniculatus & 0.28 \\
\hline & & & Prunella vulgaris & 0.1 \\
\hline & & & Sanguisorba minor & 0.1 \\
\hline & & & Scabiosa ochroleuca & 0.1 \\
\hline \multirow{10}{*}{$\begin{array}{l}\text { 15-year- } \\
\text { old stand }\end{array}$} & Calamagrostis epigeios & 20 & Calamagrostis epigeios & 20 \\
\hline & Solidago gigantea & 3.8 & Erigeron anпuиs & 1.02 \\
\hline & Erigeron annuиs & 1.02 & Achillea collina & 0.84 \\
\hline & Achillea collina & 0.84 & Daucus carota & 0.82 \\
\hline & Daucus carota & 0.82 & Crataegus monogyna & 0.68 \\
\hline & Fraxinus ornus & 0.82 & Medicago lupulina & 0.66 \\
\hline & Festuca rupicola & 0.8 & & \\
\hline & Crataegus monogyna & 0.68 & & \\
\hline & Medicago lupulina & 0.66 & & \\
\hline & Asclepias syriaca & 0.64 & & \\
\hline \multirow{17}{*}{$\begin{array}{l}\text { 20-year- } \\
\text { old stand }\end{array}$} & Fragaria vesca & 16 & Fragaria vesca & 16 \\
\hline & Brachypodium sylvaticum & 13.2 & Brachypodium sylvaticum & 13.2 \\
\hline & Calamagrostis epigeios & 10 & Calamagrostis epigeios & 10 \\
\hline & Solidago gigantea & 6.2 & Trifolium alpestre & 4.82 \\
\hline & Trifolium alpestre & 4.82 & Securigera varia & 2.6 \\
\hline & Securigera varia & 2.6 & Clinopodium vulgare & 2.24 \\
\hline & Clinopodium vulgare & 2.24 & Dactylis glomerata & 1.82 \\
\hline & Dactylis glomerata & 1.82 & Crataegus monogyna & 1.8 \\
\hline & Crataegus monogyna & 1.8 & Medicago lupulina & 1.6 \\
\hline & Salix caprea & 1.8 & Trifolium repens & 1.42 \\
\hline & & & Agrimonia eupatoria & 1.26 \\
\hline & & & Galium mollugo & 1.24 \\
\hline & & & Daucus carota & 0.86 \\
\hline & & & Achillea collina & 0.66 \\
\hline & & & Picris hieracioides & 0.28 \\
\hline & & & Sanguisorba minor & 0.28 \\
\hline & & & Rosa canina & 0.1 \\
\hline
\end{tabular}


mentioned above with high cover values were also members of the constant species group (see Table 3).

(2) 15-year-old stand: Flora developed in the reclaimed mine-pit was dominated by disturbance-tolerant and invasive plants. The ubiquitous $C$. epigeios and the alien $S$. gigantea represented $20 \%$ and $3.8 \%$ mean cover, respectively, and their joint cover exceeded $50 \%$ in some places. Among woody species, saplings of Fraxinus ornus and Crataegus monogyna appeared densely in the area. As regards for constant species Erigeron annuus, Achillea collina, Daucus carota, C. monogyna and Medicago lupulina can be mentioned beside the dominant $C$. epigeios.

(3) 20-year-old stand: High spatial variability and species richness of the herb-layer vegetation was observed with the dominance of Fragaria vesca, Brachypodium sylvaticum, $C$. epigeios and $S$. gigantea mixtured with other 11 plant species exceeded $1 \%$ in coverage. Juvenile shrubs and trees (C. monogyna, Salix caprea, Prunus spinosa, Ligustrum vulgare, Pyrus pyraster) were also found sporadically. Altogether 17 constant species were encountered in this study site (Table 3).

Increasing canopy cover of Austrian pine had significant $(\mathrm{p}<0.05)$ negative effect on the cover and the species number of herb layer (Spearman's $r_{\text {rank }}=-0.897$ and -0.662 , respectively; Figure 1), whereas had no influence on Shannon diversity (Spearman's $\left.\mathrm{r}_{\mathrm{rank}}=0.113\right)$.
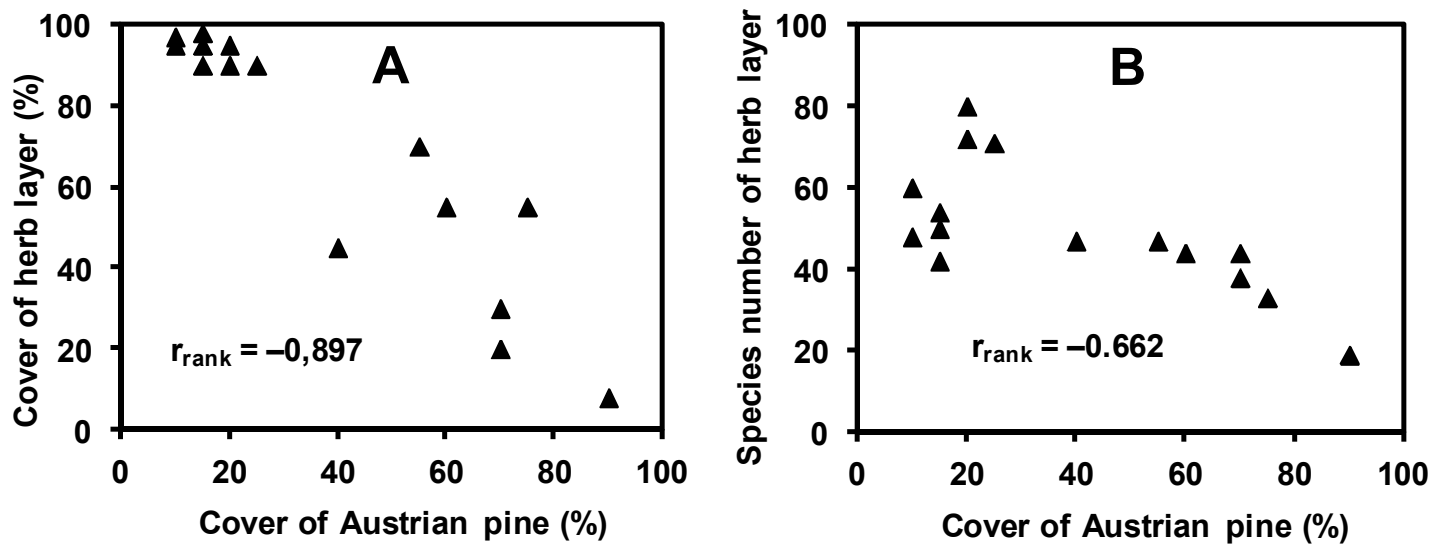

Figure 1. Change of the cover $(\boldsymbol{A})$ and the species number $(\boldsymbol{B})$ per quadrats of the herb-layer vegetation related to the cover of Austrian pine in the reclaimed bauxite quarries.

$r_{\text {rank }}=$ Spearman's rank correlation coefficient

Results of homogeneity tests of group distributions based on social behaviour types and Raunkiaer life-forms for different study sites are summarized in Table 4.

In the analysis based on the social behaviour types, homogeneity test showed significant differences among the vegetation of the three bauxite quarries (Figure 2/A, Table $4{ }^{\prime} A$ ). In the 6 -year-old pine stand, alien plants became predominant $(51.6 \%)$ mainly due to the strong invasion of $S$. gigantea, but Erigeron annuus and Conyza canadensis were present as well. High proportion of disturbance-tolerants and 
Table 4. Statistical evaluation of the vegetations developed in the reclaimed bauxite quarries. Data show $\chi^{2}$ values and levels of significance obtained from the homogeneity test of group distributions based on the ecological attributes of species.

\begin{tabular}{|c|c|c|c|}
\hline \multirow{2}{*}{\multicolumn{2}{|c|}{$\begin{array}{l}\text { Compared study sites of different ages since pine stand } \\
\text { establishment }\end{array}$}} & \multicolumn{2}{|c|}{ Ecological attribute } \\
\hline & & $\begin{array}{c}\text { Social } \\
\text { behaviour type }\end{array}$ & $\begin{array}{c}\text { Raunkiaer } \\
\text { life-form }\end{array}$ \\
\hline $\bar{A}$ & 6-year-old vs. 15 -year-old & $43.39 * * *$ & $19.37 * *$ \\
\hline & 6-year-old vs. 20-year-old & $60.76^{* * *}$ & $10.72^{\mathrm{NS}}$ \\
\hline & 15-year-old vs. 20-year-old & $74.01 * * *$ & $10.08^{\mathrm{NS}}$ \\
\hline $\bar{B}$ & 15-year-old vs. Barina [ined.] (native oak forest) & $119.2 * * *$ & $106.9^{* * *}$ \\
\hline$C^{\top}$ & 6-year-old vs. Szodfridt and Tallós [1964] (native oak forest) & $125.6^{* * *}$ & $45.54 * * *$ \\
\hline & 20-year-old vs. Szodfridt and Tallós [1964] (native oak forest) & $49.86^{* * *}$ & $24.36 * * *$ \\
\hline$D^{\prime}$ & 6-year-old vs. Csontos [1996] II stage (oak forest regeneration) & $98.38 * * *$ & $18.01 * *$ \\
\hline$\overline{E^{\top}}$ & 15-year-old vs. Csontos [1996] III stage (oak forest regeneration) & $118.2 * * *$ & $23.12 * * *$ \\
\hline & 20-year-old vs. Csontos [1996] III stage (oak forest regeneration) & $52.08 * * *$ & $15.20^{* *}$ \\
\hline
\end{tabular}

weeds as well as of indigenous ruderal competitors (principally $C$. epigeios) were detected. From among the 27 generalist species, Trifolium alpestre, Holcus lanatus and Fragaria vesca attained considerable cover. On the 15-year-old study site, herb-layer vegetation was featured by indigenous ruderal competitors (46.9\%) owing to primarily the propagation of $C$. epigeios and secondly the abundance of Cirsium arvense. Alien invaders ( $S$. gigantea, Asclepias syriaca and Ambrosia artemisiifolia) as well as 62 species classified as native disturbance-tolerants or weeds also formed important groups with $23.2 \%$ and $18.4 \%$ proportion, respectively. Natural competitors (9 species) and generalists $(20$ species $)$ formed relatively small groups in cover. The flora of the $20-$ year-old bauxite quarry was mainly composed by generalist colonizers ( 35 species with $51.1 \%$ group mass) with the predominance of Fragaria vesca and Brachypodium sylvaticum and the relatively high frequencies of Trifolium alpestre, Clinopodium vulgare and C. monogyna. However, the disturbance-tolerants and weeds (48 species, e.g. Securigera varia, Dactylis glomerata, Salix caprea) and also the indigenous ruderal species (C. epigeios, Cirsium arvense) and adventive plants ( $S$. gigantea, Erigeron annuus, Robinia pseudoacacia) were still abundant. Small percentage contribution (below $0.3 \%$ ) of both natural pioneers and specialists were obtained for each of the three reclaimed areas. The quasi-mean naturalness value calculated for the vegetations of the 6-year-old and the 15-year-old plantations proved to be very low $(-0.87$ and 0.55 , respectively) clearly due to the high cover degree of species having small naturalness value, while for the 20-year-old study site considerable higher (2.18) naturalness value was obtained.

Considering Raunkiaer life-form distributions significant difference was shown only between the herb-layer vegetations of the 6 and the 15 years old stands (Figure 2/B, Table $4{ }^{\prime} A$ '). Outstanding percentage ratio $(68.5-85.2 \%)$ of hemicryptophytes was found in each study site. Phanerophytes represented notable group mass (17.8\%) in the 15-year-old site owing to the dense regrowth of Fraxinus ornus, C. monogyna and Quercus petraea. Not more than 4.6-11.2\% relative coverage of therophytes was found, notwithstanding their relatively high species number (16-25) in each site. Each 
reclaimed site was characterized by the low ratio of chamaephyte, geophyte and hemitherophyte life-forms; although from the latter group Picris hieracioides and Centaurea biebersteinii were relatively abundant.
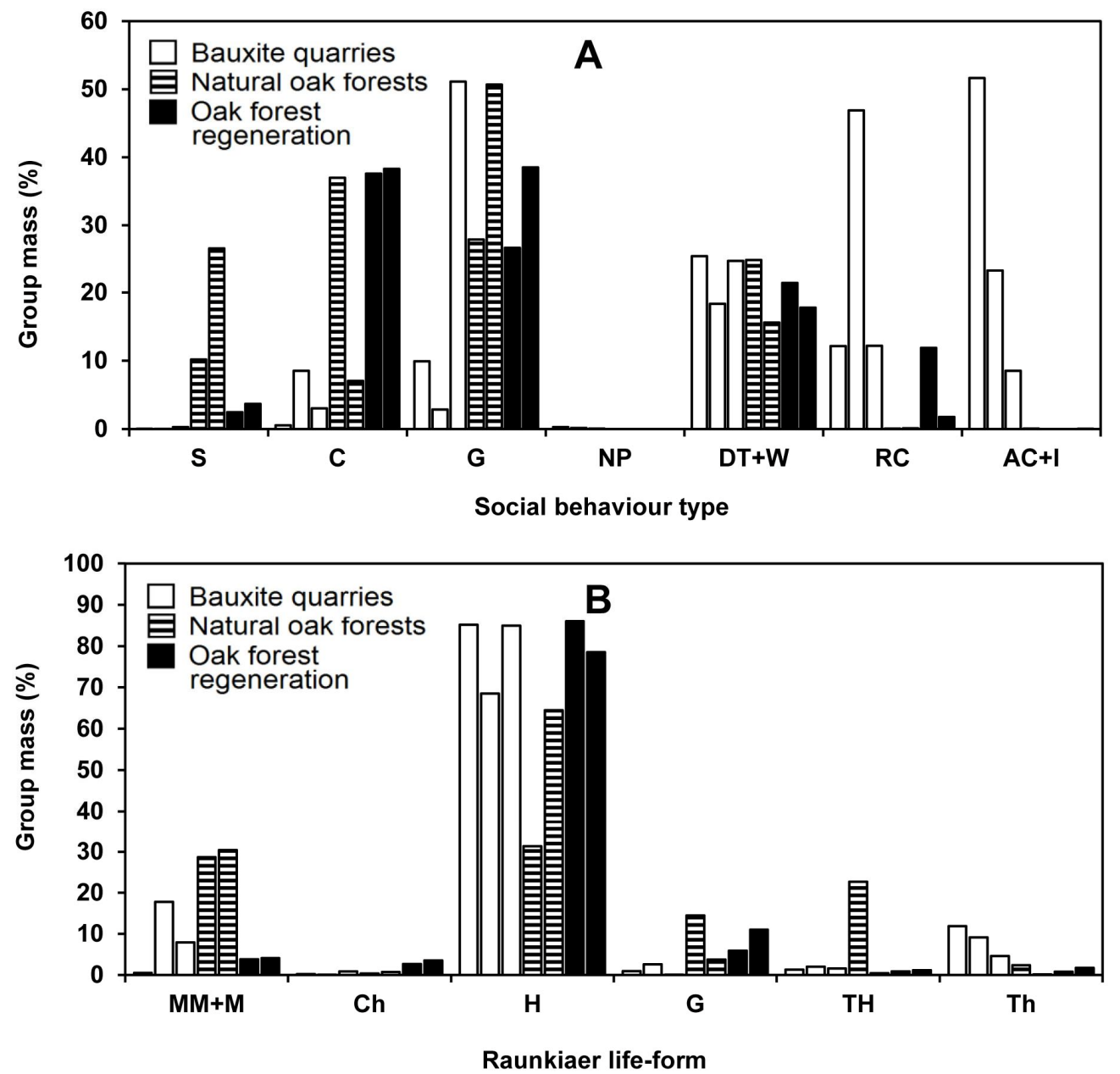

Figure 2. Group distributions of social behaviour types* (A) and Raunkiaer life-forms (B) for the herb-layer vegetation of the (i) reclaimed bauxite quarries of different ages (empty bars from left to right: 6, 15 and 20 years old stands), (ii) the natural oak forests (striped bars from left to right: Gerecse and Bakony Mts.) and (iii) oak forests regenerated after clear-cutting (filled bars from left to right: regeneration stage II and III). * $S=$ specialists; $C=$ natural competitors; $G=$ generalists; $N P=$ natural pioneers; $D T=$ disturbance-tolerants; $W=$ indigenous weeds; $R C=$ indigenous ruderal competitors; $A C=$ alien competitors; $I=$ introduced species

Further comparative evaluation of the vegetation formed in the reclamation areas was completed by employing the published (Szodfridt and Tallós, 1964; Csontos, 2010) and unpublished (Barina, ined.) data described earlier. Homogeneity tests showed significant differences in each case when group distributions calculated on the postmining flora was compared with those of generated on the basis of literature data derived from native or regenerated forest associations.

Distributions concerning the herb layer of native sessile oak - Turkey oak forests were examined at first (Figure 2). Considerable differences appeared between the flora 
of the 15-year-old reclamation area and the herb layer of Quercetum petraeae-cerris stands from Gerecse Mountains (Table 4 ' $B$ '). As regards the reclaimed bauxite quarry, the distribution of social behaviour types shifted markedly towards species groups having lower naturalness values. Oak forests were dominated by natural competitors and generalists and characterized by a remarkably higher percentage cover of specialists, whereas plenty of indigenous ruderal competitors and alien species as well as several natural pioneers featured the flora on the reclaimed site. Concerning the Raunkiaer life-forms, lower proportion of phanerophytes and geophytes as well as higher ratio of hemicryptophytes and therophytes were observed in the reclaimed areas than in the native sessile oak - Turkey oak stands. (The outstanding proportion of hemitherophytes in the oak forests of Gerecse Mts was due to the high cover of Alliaria petiolata, a species with ambiguous classification between $\mathrm{TH}$ and $\mathrm{H}$ life forms.)

The flora developed on the 6- and 20-year-old study sites was compared with the herb-layer of the native oak forest in Bakony Mountains (Table $4{ }^{\prime} C^{\prime}$; Fig. 2). Specialist species (having high naturalness value) constituted an insignificant part of coverage on the reclaimed areas, moreover here the natural competitors also represented a smaller ratio than in native oak forest. Conversely, post-mining Austrian pine stands were colonized by several natural pioneer plants as well as by the crowds of disturbancetolerant, indigenous ruderal competitor and adventive species. Phanerophyte and geophyte life-forms proved to be less frequent on reclaimed sites than in oak forest, whereas hemikryptophyte, hemitherophyte and therophyte species had higher proportion in the reclaimed sites.

In a subsequent analysis, we compared the herb layer vegetation of the reclaimed areas to the herb layer of oak forests' clearings regenerated after clear-cutting (Figure 2; Table $\left.4^{\prime} D^{\prime}\right)$. Vegetation of the 6-year-old study site was compared with the 4-11 years old successional stage of oak forest regeneration (stage-II in Csontos, 2010). Group distributions of social behaviour types showed just slight differences in proportion of either the disturbance-tolerants or the indigenous ruderal competitors. On the other hand, post-mining vegetation was predominated by adventive plants, but the regenerated forest clearings were mainly characterized by the intensive propagation of natural competitors and generalists as well as the relatively high cover degree of specialists. Apart from the uniformly high ratio of hemikrytophytes, some fundamental disparities appeared between the graphs of Raunkiaer life-forms: the reclaimed bauxite quarry seemed to be abound in therophytes and hemitherophytes, whereas was rather poor in phanerophytes, chamaephytes and geophytes.

Regarding the 15- and 20-year-old pine stands, comparison was made with the 12-21 years old successional stage of oak forest regeneration (stage-III in Csontos, 2010), (Table $4^{\prime} E^{\prime}$ ). According to the distribution of social behaviour types, species groups with low naturalness values were expressing considerable cover ratios in the reclaimed areas. In the same-aged successional stage of oak forest regeneration, natural competitors and specialists accompanied the generalist species; alien plants played an insignificant role and natural pioneers were absent. Graph of Raunkiaer life-forms (Figure 2/B) shows the higher proportion of phanerophytes, hemitherophytes and therophytes in the reclaimed bauxite quarries, whereas the higher abundance of chamaephytes and geophytes was observed in the regenerating oak forests. 


\section{Discussion}

Post-mining vegetations of different ages were clearly distinguished by the dominant species and the group distributions of social behaviour types and Raunkiaer life-forms. Herb layers of the 6,15 and 20 years old Austrian pine stands could be considered as a successional chronoseries. In the youngest (6-year-old) stand, the small species number, low Shannon diversity and evenness values were mainly caused by the dominance of $S$. gigantea and $C$. epigeios that formed altogether $60 \%$ of the vegetation cover. The remaining part of the species-pool belonged principally to disturbance-tolerants and ruderal competitors, similarly to the findings of other successional studies in the literature (Kompala-Baba and Baba, 2013). Consequently, the calculated quasi-mean naturalness value $(-0.87)$ was the lowest among the study sites. In the 15 -year-old pine stand, a smaller cover ratio of alien plants were observed, but the vegetation was still predominated by disturbance-tolerants and indigenous ruderal competitors, leading to a similarly low naturalness value $(-0.55)$. The species number, diversity and evenness of the herb layer proved to be the highest in the 20-year-old pine plantation, where the role of native broad-leaved forests' species was already important. Indigenous and alien ruderal competitors were still present, but generalists prevailed over other social behaviour types, resulting in a more favourable spectrum of the naturalness value (with the quasi-mean of 2.18). The increasing pine canopy cover reduced the cover and species number of the herb layer but no change in Shannon diversity was detected. The independence observed between pine cover and herb layer diversity can be explained by the excessive spreading of $C$. epigeios and $S$. gigantea in the open quadrats, causing a reduction of both evenness and diversity. Rapid propagation of $C$. epigeios through the early stage of regenerative succession, as well as its penetration to various forest communities were also observed in Central Europe (Sierka and Chmura, 2005; Mudrák et al., 2010). Házi et al. (2011) suggested an artificial control of C. epigeios by regularly repeated mowing in order to promote the appropriate course of succession. Negative effect of Austrian pine cover on species number and fine-scale structural complexity of the herb-layer vegetation was reported earlier as well (Bartha et al., 2004; Mudrák et al., 2010).

Indigenous ruderal and alien competitors as well as natural pioneers were nearly absent from the native sessile oak - Turkey oak associations, furthermore habitatindifferent plants were substituted by species of broad-leaved forests. According to the social behaviour types, these species mainly belonged to the specialists, natural competitors and generalists, contributing to a much higher naturalness of sessile oak Turkey oak forest. As for Raunkiaer life-forms, both the species number and relative coverage of phanerophytes exceeded the values determined for the reclamation areas and the proportion of therophytes were lower in oak forests due to the subordinate role of weeds. Conspicuous difference appeared between group masses of geophytes as well. Geophytes amounted to 5-15\% cover ratio in the native oak forests, whereas they were absent from the reclaimed sites. Extreme low colonization ability and slow propagation of geophytes was also demonstrated during various secondary succession studies (Schmidt, 1988; Hayashi, 1991).

Herb-layer vegetation in the reclaimed areas expressed characteristic changes along with the aging of Austrian pine stands. Cover ratio of indigenous ruderal and alien competitors decreased gradually in parallel with the increasing role of the botanically more valuable generalists, natural competitors and specialists. An upward trend for the accompanying forest species group is also established on the reclaimed areas, as their

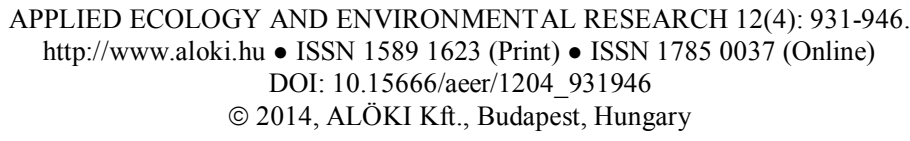


initial $2.5 \%$ cover rate (at the 6-year-old stand) increased to $29.5 \%$ (at the 20 -year-old stand). However, even the latter proportion falls far behind the $73 \%$ relative cover of this group found in the herb layer of natural sessile oak - Turkey oak forests (Szodfridt and Tallós, 1964; Kevey, 2008). Hemitherophytes and therophytes become repressed gradually parallel to the ageing of the reclaimed areas but the recurrence of geophytes did not occur. Such long-time changes in life-form and phytosociological spectra of the vegetation proved to be characteristic successional trends observed in different types of primary and secondary successions in infertile substrates, as confirmed by several field studies (Schmidt, 1988; Bartha et al., 2004; Frouz et al., 2008). Protected plants were absent from the reclaimed areas although several of them were frequently detected in the surrounding natural associations (Barina, ined.; Barina, 2006; Szodfridt and Tallós, 1964; Kevey, 2008).

Vegetation regenerated after the clear-cutting of sessile oak - Turkey oak forests (Csontos, 2010) also differed significantly from the flora formed on reclamation areas. Natural pioneers and adventive species were missing in stage II (4-11 years old) of the regenerative succession, but the latter group contributed nearly $52 \%$ of the cover in the 6 -year-old reclaimed site. A particularly great inequality was shown for natural competitors representing about $0.5 \%$ proportion in the 6-year-old reclaimed site, whereas the herb layer of regenerating forest clearings was predominated $(37.6 \%)$ by this social behaviour type. The graph of Raunkiaer life-forms clearly shows both the notably higher ratio of geophytes and the low cover degree of therophytes on the regenerating forest clearings. Additionally, vegetation of this early successional stage of clearings was already featured chiefly by the mixture of accompanying species $(62 \%)$ instead of disturbance-tolerants and ruderal plants which were characteristic on the reclaimed sites.

By comparing the flora of the 15 and 20 years old post-mining pine stands with the successional stage III (12-21 years old) of oak forest regeneration (Csontos, 2010), differences proved to be similar in many respects, and a more pronounced disparity were obtained for the middle aged than for the older reclaimed stand. The herb layer of the regenerating oak forest clearings was richer in specialists and natural competitors, but conversely poorer in indigenous ruderal competitors than the reclaimed areas. Distribution of Raunkiaer life-forms displays the considerable cover rate of geophytes (11\%) and the lower proportion of hemitherophytes and therophytes, in relation to reclamation areas. Oak forest clearings were dominated by the accompanying species of broad-leaved forests in this successional stage. Several protected species (e.g. Doronicum hungaricum, Iris graminea, Lilium martagon, Lychnis coronaria) were already established in the successional stage II of oak forest regeneration, followed by others (e.g. Cephalanthera longifolia, Epipactis helleborine, Neottia nidus-avis) in stage III (Horváth and Csontos, 1992; Csontos, 2010), whereas protected species were absent from the vegetation of the reclaimed sites.

We can conclude that the herb layer of post-mining Austrian pine stands passes through similar processes of regenerative succession than does the vegetation developed on clearings of formerly clear-cut native sessile oak - Turkey oak forests. However, the revegetation by spontaneous succession takes place more slowly or just partially in Austrian pine stands, thus the naturalness of the post-mining vegetation is always falls behind the same-aged stage of oak forest's regeneration. It corresponds to the characteristic differences between regeneration succession and secondary succession (Maarel, 1988), as the former takes place on oak forest clearings but the latter is the 
governing process on the reclaimed sites. In the reclaimed quarries, adventive plants may become abundant quickly, while the proportion of natural broad-leaved forests' species increases their share slowly. In addition, the major part of the constant oak forest species (particularly the specialists) does not occupy the reclaimed areas even after 20 years. Weak soil ameliorative effect of Austrian pine and its negative influence on the recolonization of native vegetation was formerly observed and silvicultural interventions, mainly small-scale and diffuse gap-opening in pine canopy was proposed for promoting natural succession (Barčić et al., 2006; Jonášová et al., 2006). However, it should be taken into consideration that plant recolonization in the post-mining areas can be strongly prevented by the deficiency of propagules which were presumably available on clearings regenerated after clear-cutting (surviving specimens, soil seed bank, bulbs, rhizomes etc.), but obviously absent from the top layer of reclaimed quarries. Spreading of propagules was found to be a crucial factor for plant migration and recolonization in disturbed areas that could strongly determined the course of regenerative succession (Matlack, 1994; Lanta and Leps 2009). For better understanding the consequences of Austrian pine application, long-term ecological monitoring of several reclamation areas should be initiated with involving unforested control sites receiving technical reclamation only. Nevertheless, presented results suggest the obstructive effect of Austrian pine on secondary succession, thus further establishment of pine stands can be reasonable just in case when the unfavourable habitat conditions (water management, nutrient supplying ability) do not make possible the utilization of other tree species in the spoil area. Hodačová and Prach (2003) realized that spontaneous succession could be an advantageous alternative to technical reclamation, leading to more natural vegetation with much higher species diversity. Consequently, existing pine stands have been created for silvicultural reclamation should not be maintained for decades. These plantations can be provisionally effective for preventing both water and wind erosion, but their conversion to the locally native vegetation types should be made as early as possible to achieve a perfect restoration goal.

Acknowledgements: Many thanks are due to foresters István Szakács, Balázs Kercselics and Mátyás Hartdégen for their help in data collection concerning Austrian pine stands.

\section{REFERENCES}

[1] Baranyi, K. (1986): Tapasztalatok szeméttelepek fásításával. [Afforestation of rubbishheaps.] - Az Erdö 35: 276-279.

[2] Barina, Z. (2006): A Gerecse hegység flórája. [Flora of Gerecse Mountains.] Rosalia, 1. kötet. - Magyar Természettudományi Múzeum, Duna-Ipoly Nemzeti Park Igazgatósága, Budapest.

[3] Barčić, D., Hršak, V., Španjol, Ž. (2006): The ameliorative effect of pine cultures on forest sites on the island of Rab in Southwest Croatia. - Forest Ecology and Management 237: 39-46.

[4] Bartha, S., Campetella, G., Canullo, L., Bódis, J., Mucina, L. (2004): On the importance of fine-scale spatial complexity in vegetation restoration studies. - International Journal of Ecology and Environmental Sciences 30: 101-116. 
[5] Baumann, K., Rumpelt, A., Schneider, B. U., Merschner, P., Hüttl, R. F. (2006): Seedling biomass and element content of Pinus sylvestris and Pinus nigra grown in sandy substrates with lignite. - Geoderma 136: 573-578.

[6] Bódis, J. (1993): A feketefenyő hatása nyílt dolomitsziklagyepre. I. Texturális változások. [Degradation of dolomite grassland communities due to Pinus nigra plantation. I. Textural changes.] - Botanikai Közlemények 80: 129-139.

[7] Borhidi, A. (1995): Social behaviour types, the naturalness and relative ecological indicator values of the higher plants of the Hungarian flora. - Acta Botanica Hungarica 39: 97-181.

[8] Cseresnyés, I., Szécsy, O., Csontos, P. (2011): Fire risk of Austrian pine (Pinus nigra) plantations under various temperature and wind conditions. - Acta Botanica Croatica 70: 157-166.

[9] Cseresnyés, I., Csontos, P. (2012a): Soil seed bank of the invasive Robinia pseudoacacia in planted Pinus nigra stands. - Acta Botanica Croatica 71: 249-260.

[10] Cseresnyés, I., Csontos, P. (2012b): Feketefenyővel rekultivált bauxit külfejtések vegetációjának természetvédelmi szempontú értékelése. [Vegetations of abandoned openpit bauxite mines reclaimed with Austrian pine - A nature conservation assessment.] Tájökológiai Lapok 10: 315-340.

[11] Csontos, P. (2010): Light ecology and regeneration on clearings of sessile oak - Turkey oak forests in the Visegrád Mountains, Hungary. - Acta Botanica Hungarica 52: 265286.

[12] Csontos, P., Tamás, J., Kalapos T. (1997): Soil seed banks and vegetation recovery on dolomite hills in Hungary. - Acta Botanica Hungarica 40: 35-43.

[13] Csontos, P., Halbritter, A., Tamás, J., Szili-Kovács, T., Kalapos, T., Uzinger, N., Anton, A. 2012. Afforestation of dolomite grasslands with nonnative Pinus nigra in Hungary and its effect on soil trace elements. Applied Ecology and Environmental Research 10(4): 405-415.

[14] Fettweis, U., Bens, O., Hüttl, R. F. (2005): Accumulation and properties of soil organic carbon at reclaimed sites in the Lusitanian lignite mining district afforested with Pinus sp. - Geoderma 129: 81-91.

[15] Filcheva, E., Noustorova, M., Gentcheva-Kostadinova, S., Haigh, M. J. (2000): Organic accumulation and microbial action in surface coal-mine spoils, Pernik, Bulgaria. Ecological Engineering 15: 1-15.

[16] Frouz, J., Prach, K., Pižl, V., Háněl, L., Starý, J., Tajovský, K., Materna, J., Balík, V., Kalčík, J., Řehounková, K. (2008): Interactions between soil development, vegetation and soil fauna during spontaneous succession in post mining sites. - European Journal of Soil Biology 44: 109-121.

[17] Hayashi, I. (1991): Secondary succession of herbaceous communities in Japan: a case study in Sugadaira, Central Japan. - Bulletin of Sugadaira Montane Research Center 12: $1-12$.

[18] Házi, J., Bartha, S., Szentes, S., Wichmann, B., Penksza, K. (2011): Seminatural grassland management by mowing of Calamagrostis epigeios in Hungary. - Plant Biosystems 145: 699-707.

[19] Hodačová, D., Prach, K. (2003): Spoil heaps from brown coal mining: Technical reclamation versus spontaneous revegetation. - Restoration Ecology 11: 385-391.

[20] Horváth, Gy. (2002): Veszélyes ipari hulladékok rekultivációja erdősítéssel. [Silvicultural reclamation of hazardous industrial wastes.] - Erdészeti Lapok 137: 17-19.

[21] Horváth, F., Csontos, P. (1992): Thirty-year changes in some forest communities of Visegrádi Mts., Hungary. - In: Teller, A., Mathy, P., Jeffers, J. N. R. (eds.) Responses of forest ecosystems to environmental changes, pp. 481-488. Elsevier Applied Science, London.

[22] Hutcheson, K. (1970): A test for comparing diversities based on the Shannon formula. Journal of Theoretical Biology 29: 151-154.

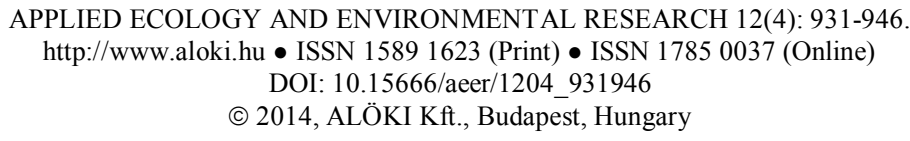


[23] Jochimsen, M. E. (2001): Vegetation development and species assemblages in a longterm reclamation project on mine spoil. - Ecological Engineering 17: 187-198.

[24] Jonášová, M., Hees, A. van, Prach, K. (2006): Rehabilitation of monotonous exotic coniferous plantations: A case study of spontaneous establishment of different tree species. - Ecological Engineering 28: 141-148.

[25] Károly, F., Legeza, M., Stubán, Z. (2006): Az iharkút-németbányai külfejtések rekultivációja. [Reclamation of 'Iharkút-Németbánya' open-pit mine.] - Bányászati és Kohászati Lapok - Bányászat 139: 31-37.

[26] Kevey B. (2008): Magyarország erdőtársulásai. [Forest associations of Hungary.] - Tilia 14: 3-489.

[27] Kompala-Baba, A., Baba, W. (2013): The spontaneous succession in a sand-pit - the role of life history traits and species habitat preferences. - Polish Journal of Ecology 61: 1322.

[28] Kovács, B. (1998): A külfejtéses bauxittermelést követő rekultiváció eredményei a Dunántúli-középhegységben. [The results of reclamation following opencast bauxite mining.] - Földrajzi Értesítő 47: 197-207.

[29] Lanta, V., Leps, J. (2009): How does surrounding vegetation affect the course of succession: A five-year container experiment. - Journal of Vegetation Science 20(4): 686-694.

[30] Liu, Y., Naidu, R., Ming, H. (2011): Red mud as an amendment for pollutants in solid and liquid phases. - Geoderma 163: 1-12.

[31] Maarel, E. van der (1988): Vegetation dynamics: patterns in time and space. - Vegetatio 77: 7-19.

[32] Maarel, E. van der (2007): Transformation of cover-abundance values for appropriate numerical treatment - Alternatives to the proposals by Podani. - Journal of Vegetation Science 18: 767-770.

[33] Matlack, G. R. (1994): Plant species migration in a mixed-history forest landscape in Eastern North America. Ecology 75: 1495-1502.

[34] Miletić, Z. D., Stefanović, T. P., Stajić, S. A., Čokeša, V. M., Radulović, Z. B. (2011): Effect of forest plantations on erodibility of reclaimed lignite mine soils. - Polish Journal of Environmental Studies 20: 987-992.

[35] Mudrák, O., Frouz, J., Velichová, V. (2010): Understory vegetation in reclaimed and unreclaimed post-mining forest stands. - Ecological Engineering 36: 783-790.

[36] Novák, S. (2007): Bauxitbányászat a Gerecse térségében, Bicske környékén. [Bauxite mining near Bicske, Gerecse Mountains.] - Bányászati és Kohászati Lapok - Bányászat 140: 29-33.

[37] Pratas, J., Prasad, M. N. V., Freitas, H., Conde, L. (2005): Plants growing in abandoned mines of Portugal are useful for biogeochemical exploration of arsenic, antimony, tungsten and mine reclamation. - Journal of Geochemical Exploration 85: 99-107.

[38] Richardson, D. M. (1998; ed.): Ecology and Biogeography of Pinus. - Cambridge University Press.

[39] Schmidt, W. (1988): An experimental study of old-field succession in relation to different environmental factors. - Vegetatio 77: 103-114.

[40] Sierka, E., Chmura, D. (2005): Role of Calamagrostis epigejos in forest communities of Silesian Upland (S Poland). - In: Frey, L. (ed.) Biology of grasses, pp: 343-352. W. Szafer Institute of Botany, Krakow.

[41] Simon, T. (2000): A magyarországi edényes flóra határozója. [Vascular plants of Hungary.] - Nemzeti Tankönyvkiadó, Budapest.

[42] Szalai Z, Szabó M, Zboray N, Kiss K, Horváth-Szabó K, Jakab G, Balázs R, Németh T, Madarász B (2012): Relationship between ecological indicators and soil properties (in case of a wetland) Hungarian Geographical Bulletin - Földrajzi Értesítő 61:(3): 187-196.

[43] Szerémy, P. (1981): Felhagyott bányaterületek erdősítésének lehetősége a Mecsekben. [Reclamation of abandoned mines in Mecsek Mountains.] - Az Erdő 30: 228-230.

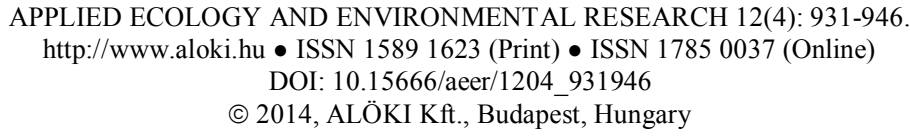


[44] Szodfridt, I., Tallós, P. (1964): A felsőnyírádi erdő cseres-tölgyesei. [Oak forests in Felsőnyírád.] - Veszprém Megyei Múzeumok Közleményei 2: 423-435.

[45] Tamás, J. (2003): The history of Austrian pine plantations in Hungary. - Acta Botanica Croatica 62: 147-158.

[46] Török, K., Botta-Dukát, Z., Dancza, I., Németh, I., Kiss, J., Mihály, B., Magyar, D. (2003): Invasion gateways and corridors in the Carpathian Basin: biological invasions in Hungary. - Biological Invasions 5: 349-356.

[47] Woźniak, G., Chmura, D., Błońska, A., Tokarska-Guzik, B., Sierka, E. (2011): Applicability of Functional Groups Concept in Analysis of Spatiotemporal Vegetation Changes on Manmade Habitats. Polish Journal of Environmental Studies 20: 623-631.

[48] Zagas, T., Tsitsoni, T., Ganatsas, P., Tsakaldimi, M., Skotidakis, T., Zagas, D. (2010): Land Reclamation and ecological restoration in a marine area. - International Journal of Environmental Research 4: 673-680.

[49] Zólyomi, B. (1989): Természetes növénytakaró. [Natural vegetation.] - In: Pécsi, M. (ed.) Magyarország Nemzeti Atlasza [National atlas of Hungary], p.89, Kartográfiai Vállalat, Budapest. 